\author{
Радоје Д. СИМИЋ ${ }^{*}$ \\ Универзитет у Београду \\ Филолошки факултет \\ Катедра за српски језик са јужнословенским језицима
}

\title{
ЈЕДНИНА ОПШТИХ (ЗАЈЕДНИЧКИХ) ИМЕНИЦА СА ЗНАЧЕЊЕМ МНОШТВА У СРПСКОМ ЈЕЗИКУ
}

\begin{abstract}
Аутор је подстакнут на размишљање о теми из наслова једним на први поглед ефемерним и тривијалним случајем - упозорењем у градским аутобусима: „Драги путници, молимо вас да поништите вашу карту"'. Овде једнина 'карта' не стоји за појединачни предмет означене врсте, већ за мноштво које се овде обележава 'дистрибутивним' путем. Други случај чине исто тако тривијални случајеви типа: „Стара 'застава 101' више одговара нашим условима него страни типови аутомобила”. Овде се 'застава 101' не односи на појединачно возило, већ читаву класу обележену датом шифром. Сматрамо да је ту у питању 'опште' значење у правом смислу речи. Овакви и слични примери биће анализирани у овом прилогу.

Кључне речи: именица, једнина, множина, значење, властита имена.
\end{abstract}

\section{1. Опште напомене}

1. А. Белић у својим размишљањима о природи и развитку језика каже о именицама између осталог и следеће: „Правим именицама ја називам за наше језичко осећање немотивисане именичке речи које значе реалне предмете или такве појмове којима се обележава збир особина каквог предмета" (Белић 1998: 43). 'Збир особина' замислив је као апстрактни ентитет који чине екстрахована спознатљива својства неког реалног или духовног 'предмета' заједничка целом скупу или врсти. То су, дакле, врсни називи чији садржај чине особине датог предмета (јабука, камен, мисао, жалост) а опсег - сви носиоци тих особености. Овај моменат оспособљава именицу да се употреби као назив и датог појединачног предмета, и одређеног скупа, али и врсте као апстракције којом је обухваћен цео репертоар датих реалија.

\footnotetext{
*jelenajo@bitsyu.net

${ }^{1}$ Стилски би било исправније 'своју карту', али је исказ и овако прихватљив.
} 
2. По М. Стевановићу (1991: 181-182): „Општи називи за жива бића и предмете са заједничким особинама као што су именице: борац, друг, пријатељ, јелен, седло, перо, чело, брдо, поље, њива, кућа, крушка, река, шума, варош, пећ, ствар, трун, штап, школа и друге ове врсте - јесу заједничке именице."

3. Није потребна даља расправа па да увидимо и да опште именице заправо јесу врсни називи, што значи да означавају скупове јединки истих особености ('збира особина'). Проблем постаје како ове речи означавају једнину, тј. појединачни случај из свог садржаја. Али ми се нећемо тиме бавити са чисто теоријског становишта, већ ћемо се поставити у позицију обичног посматрача, са чијег гледишта именице 'коњ', 'сто', 'кокош' итд. упућују на појединачни предметни елеменат стварности. За мноштво предмета одговарајуће врсте употребљава се специјални облик, или низ (падежних) облика, са значењем множине: 'коњи', 'столови', 'кокоши' итд. Али изван овако постављене регуларне дистрибуције облика, дешава се да једнина ових речи такође на известан начин упућује на мноштво предметних или других реалија дате врсте. Делом су то тривијални случајеви који се готово свакодневно јављају у говорном и писаном изразу, али делом су ређи и не сасвим обични. Описаћемо их разгледајући грађу из уметничке прозе, у којој је стање у вези с тим појавама, рекло би се, слично као у разговорном језику свакодневице.

\section{2. Преглед грађе}

1. Узећемо најпре два следећа случаја, који на први поглед по свој прилици не изгледају обично, али ипак су обични:

Оне обе носиле су дугу ирну кецељу, просту витииу око главе, сукњу изнад чланака, притискивале по један свежањ књига на груди... - Ускоковић 2004: 23.

По тротоару, с друге стране, ишле су две жене, са марамом на глави, чији су крајеви били везани испод браде. - Ускоковић 2004: 154.

a) Познати књижевник описује женску ношњу свога времена. У првом случају предмет описа су две ученице. Оне између осталог, како се на крају тврди, носе „по један свежањ књига на грудима”. Речца 'по' има дистрибутивно значење, и сугерира да свака од девојчица носи свој 'свежањ књига', те да их је укупно два.

б) Али на почетку исказа који анализирамо стоји, додуше, наглашено, да су 'обе' једнако опремљене, а онда даље стоји да су „носиле [...] дугу црну кецељу, просту витицу око главе, сукњу изнад чланака" итд. Неки слабије домишљат малишан или странац - могли би помислити да су се обе увукле у једну кецељу или сл. Но просечни говорник српског језика недвосмислено разуме да је реч о две кецеље, два пара витица, две сукње... - и да је свака од њих имала на себи по једну, одн. један пар. Могло би се и ту укључити 'по', као што га укључисмо у анализи, па да значење дистрибутивности буде прецизирано, али то није обавезно било, па није ни учињено. На себе је то значење преузео сам облик једнине, наравно - ослонивши се на контекст и ситуацију употребе.

в) И у другом примеру реч је о две особе и њиховој ношњи. Свака од њих носила је мараму везану испод браде. Несумњиво су биле две мараме, и везане испод две браде, па ипак је употребљена једнина. 


\section{2. Врло су сличне прилике и у примеру који ћемо сада прегледати:}

- Размрдај се, болан, Тодоре. Ево да припалимо једну, па да је сто послова. - Ћопић 1966: 97.

Онај ко изговара наведени исечак из дијалога двојице актера Ћопићеве приче свестан је, наравно, да су по сили природног закона ту заправо две цигарете (нема речи да се из немаштине обојица служе једном). Али и поред тога употребљава једнину.

3. У сва три наведена случаја значење множине је без даљњег јасно - и јасно је да је реч о дистрибутивном значењу једнине са множинским смислом. Одмах ваља рећи да је овде у питању метонимија, али и додати да је метонимија на неки начин принудног карактера. Нема овде разлога мислити на намеру стилског 'украшавања' већ је пре у питању потреба увођења извесне разноликости у израз ради евентуалног превладавања монотоније. Али има и других, нешто друкчијих примера употребе једнине.

3.1. Узећемо узгред и следећи пример:

Све је село заједно са сељацима променило физиономију своју. Не видиш више босе ноге, ни кратке рукаве, ни папучица, ни цицаних сукњица; све се то, и мушко и женско, и старо и младо, фатирало и убантурало добро. На глави шубаре јагњеће или астраганске, на плећи изврнут кожух или дорои и шарена кабаница... - Сремац 1977: 213.

Прелазак са множине на једнину и са једнине на множину заиста је изненађење (босе ноге... - шубаре - кожух, дороц). Можда је од значаја у томе била заменица 'све', са својим системским значењем збирности (све - и мушко и женско, и старо и младо...), која је онда повукла и остале одсечке на варијацију, овде на смену једнине и множине.

3.2. Имамо два примера у којима је једнином управо потенцирано мноштво, у оба случаја људи:

- Ајме, мајко јадна, ето их [Италијана] из вароши пљева и мрав! Има их на милијуне! - Ћопић 1966: 515.

Био вашар, велики годишњи вашар, па се слегло ту све и сва. Гмиже народ као мрав... - Нушић 2003: 29.

а) Извештај о навали Италијана на Подгорину у Ћопићевом роману сав је прожет страхом. Зато је податак о броју тако потенциран да све заједно прераста у упечатљиву хиперболу.

б) У другом, успешним поређењем мноштва народа са мравима појачан је и стилски врло побољшан једнинским обликом 'мрав'. Изненађујуће је да се једнином може постићи тако снажан стилски утисак о мноштву. Но ми заборависмо да размислимо који је тип мноштвеног значења овде постигнут. О дистрибутивности нема ни речи. Најбоље је овде употребити термин 'збирност', или 'комплетивност' : значење великог недиференцираног скупа јединки.

3.3. Згодно је место да погледамо још једно поређење у којем учествује једнина, али зачудо са својим основним значењем:

[...] видиш и глупе покисле кокошке и још глупље и мизерне ћурке (које ти изгледају као каква стара кокета сутрадан после бурнога бала), како су се скупиле и ћуте, ћућоре покаткад или пућну од времена на време. - Сремац 1977: 213-214. 
Није јасно како „глупе покисле кокошке и још глупље и мизерне ћурке” могу изгледати као „стара кокета”, а не као „старе кокете”. Можда се овде ради о недозвољеној дисконгруенцији, а можда је овакво слагање и регуларно. Углавном се једнина ипак мора тумачити збирно, као да свакој ћурки одговара једна 'стара кокета', или обратно, како хоћемо.

3.4. Још једно изненађење за теоретичара представљају случајеви које ћемо анализирати у овој тачки:

Сад је, сједећи у мутваку и пушећи, причао о Шваби, који је с топовима и великом спремом већ код Јајца, и о Турцима, који се спремају да га дочекају у Клокотима. - Андрић 1963а: 161.

Инглез затворио пут преко мора, па Бунапарти нестало памука. А треба одијевати толику војску. Па сад ваља да шаље памук преко Босне. Од Новог Пазара до Костајнице све је коњ до коња и дењак до дењака, све сам памук [...] Не мореш нигдје добити кириџије, све Француз закупио и све здравим дукатом плаћа [...] - Андрић 1963в: 368.

У сваком њиховом питању и примједби осјећало се тешко колебање [...] између јасног и одлучног става Партије према непријатељу и оне слијепе и глуве тежње кратковидог и судбини преданог сељаштва да се све препусти току твари, доброј вољи Талијана и неизвјесним изгледима на скоро смирење. Неће ни под Талијаном баш лако бити, главно је само да он човјеку остави главу, а бог је дао дурање које је надживјело и савладало и веће невоље, па ће и Талијане. - Ћопић 1966: 470.

- Шта ћемо ког ђавола у вароши, није то за нас. Кад једном доље заглавиш, враг те више не извуче. - Ваљда да се доље са усташама за здравље питамо - и да нас Талијан разоружа. Ко ће њему вјеровати. -Ћопић 1966: 536.

- Дедер, ко ти је тај Талијан, ко га је овамо звао, зашто је дошао?! Знаш ли му шта говори, како му је код куће, шта му раде чељад? Ништа ти од њега под милим богом не знаш. - Ћопић 1966: 539.

- E, не прича нама Талијан шта кани кад уреди ове наше комшије. Да не дође откуда ред и на нас? - Ћопић 1966: 539.

Мирило их је и суздржавало само то што им је заједнички непријатељ био јак и одвише близу, а под заједничким покровитељем, Талијаном, ваљало се показати ревносним и послушним. - Ћопић 1966: 548.

- Прича се да Талијан шаље на нас некакве Арапе... - Ћопић 1966: 549.

а) Андрићев исказни сегмент „причао о Шваби, који је с топовима и великом спремом већ код Јајца” првим делом привидно најављује сингулатив, дакле појединачност случаја. Али адвербијал 'с топовима и великом спремом' демантује тај утисак и отвара поглед на мноштво предметних елемената, који је несавладив појединачним деловањем, који као у својеврсној гротесци неопходно захтева множину. Тако и једнински облик 'Швабо' принудно добија опште значење, подразумевајући под једнинским називом - колектив.

б) „Инглез затворио пут преко мора” не односи се, наравно, на појединачног Енглеза, већ на Енглезе (или на Енглеску!) као скупни факат.

в) Слично је, и свуда истог типа, и значење именице 'Талијан' у низу примера који следе за овим.

г) Овај се тип значења не може подвести под горње термине збирности и колективности. Парадоксално је, али у овом случају истинито: да властито име које може имати множинске облике - својим једнинским обликом овде преузима значење карактеристично за опште именице - управо 'опште' значење.

4. Чудно је, али не као у управо анализираним случајевима - и значење речи у већем броју иначе различитих типова употребе општих именица. 


\section{1. Размотрићемо најпре како ствари стоје у следећим примерима:}

Тирани и деспоти су једини владари који владају уз подршку апсолутне већине народа. У демократском друштву политичар на власти може имати подршку релативне већине и власт на кратко време. - Ћосић 2009: 224-225.

„Прође лето”, рекла би тек вредна домаћица, „окраћо дан... Не зна човек кад му прође дан... Нестало оног ведрог и насмејаног неба, покрили га сиви облаци који се поваздан гоне, стижу и престижу. Осећа се човек под њим као војник под прокислим и мокрим шатором.” - Сремац 1977: $211-212$.

Тешко се било домислити лукавству опрезног и плашљивог сељака коме је читав живот био усмјерен на то да све своје, било то имање, какав посао или чак намјера, склања и укрива од злог ока и невидовне напасти... - Ћопић 1966: 209.

Ови варошани, ситан малограђански свијет, били су не само на терет човјеку код кога су одсјели, него су по мало били напаст за читаву околину. - Ћопић 1966: 443.

[...] овај бродоломни свијет сваком је одмах падао у очи и већ самом својом појавом подсјећао сељаке на рат и на то да човјек данас може зачас остати без игдје ичега и пасти на врат бог те пита коме. - Ћопић 1966: 472.

a) На питање ко је 'политичар на власти' из првог овдашњег случаја - одговор може гласити - 'сви који су, одн. свако ко је на власти'. У првом случају мисли се на мноштво, али у другом на селективног појединца: 'онај појединачни који је на власти'. Именица, према томе, може бити објашњена као да има опште, збирно, али и неодређено сингулативно значење.

б) Нема потребе доказивати да су у истој позицији и именице 'човек', 'војник', 'сељак' итд. у следећим нашим примерима.

4.2. Следе две групе примера у којима је једнински облик принудно употребљен услед деловања контекста или конструктивне схеме:

Многи је босански спахија, бранећи свој угарски спахилук, у борбама при том повлачењу, оставио кости у мађарској земљи. - Андрић 1963б: 78.

Многи угледнији муслиман био је тих дана премлаћен од стране непознатих људи... - Ћопић 1966: 462.

Идући са капетаном по срезу, виде Марко многу невољу... - Домановић 1967: 41.

[...] самоникле улице по Чубури виделе су тада многи млади пар. - Ускоковић 2004: 30.

Сви су били студенти, равни један другоме. - Ускоковић 2004: 66.

После би по групама пратили једно друго до куће. - Ускоковић 2004: 91.

а) У прва два случаја налазимо заменицу 'многи', коју обично схватамо као множински облик који и значи мноштво. Овде је, међутим, она схваћена као једнинска форма, па је према њој и именица употребљена у једнини. Многи ће граматичар овде застати и рећи да је наша анализа наопака, јер конгруенција значи прилагођавање атрибута управној именици, а ми тврдимо обрнуто. Но ипак се ово осећа само као варијација конструкције са рекцијским односом: 'много муслимана' // 'многи муслиман', 'много младих парова' // 'многи млади пар'. Као што примећујемо, последица ове варијације видна је у стилском ефекту - одн. у знатном стилском појачању израза.

б) У друга два наша примера употребљен је заправо идиоматизован израз у две варијанте, и са необичним синтаксичким односом делова. 
б1) Форма 'један другоме' садржи основни број 'један' и редни 'други' у посредној синтаксичкој вези која је објашњива преко предиката 'били су': 'равни' је предикатив, или боље, апозитив предикатива 'студенти', а 'другоме' његова допуна у дативу користи. 'Један' би у том случају био субјекат реченице. Предикат 'били су' и предикатив су у множини 'једнаки', и упућују на мноштво, док 'један' и 'други' стоје у једнини.

б2) Форма 'једно друго' протумачива је на сличан начин: састоји се од субјекта 'једно', објекта у акузативу 'друго' и предиката 'пратили би'.

4.3. Уместо у множини, околне речи у управо анализираним случајевима, сем множинског, могу имати и једнински облик, што је стилски ефектније, али и лингвистички интересантно:

Свуда свет, једно до другог, припијено, загушено, са свећом у руци, и сваки час крстећи се, понавља молитве или песме што допиру из цркве. - Станковић 1957: 22.

Није јасно где је извор критерија за конгруенцију. Може се, наиме, помислити да „свет... понавља молитве”. Али пошто је он сувише удаљен, боље је устврдити да је он управо у конструкцији 'једно до другог', иако је она у положају апозиције субјекта (можда баш зато). Но и овај закључак није сасвим прецизан, јер је вероватније у том случају претпоставити да је слагање облика обављено ипак са поласком од најближег члана конструкције: 'друго'. Тада идеја о множинском значењу заправо сасвим отпада.

5. Плурална семантика као да је ишчезла из именице и у случајевима које ћемо сада узети у разматрање.

5.1. Погледаћемо најпре како ствар стоји у следећим случајевима:

И давно необријан сељак, Тривунов четник, с гладном дивљом тугом гледао је у вршак школског крова на ивици свог села. - Ћопић 1966: 538.

Задубен тако у те горке мисли, четник би се одједном пренуо, мрским огледом одмјерио ровове и талијанске бункере, и упитао се... - Ћопић 1966: 545.

5.2. Досад није било речи о могућности прономинализације, тј. замене именичке речи у једнини заменичком у истом облику, и о последицама које из тога произлазе. Сада ћемо навести два таква случаја и размотрити их:

- Видиш ли ти, довукло је то [Италијани] и авијацију на нас. - Ћопић 1966: 515.

- Повући ћемо се у правцу вароши... - A, јок, јок, неће ти ова наша братија на то пристати! - бунио се Тривун. Воли се он повући у планину и горе се смрзавати, само да може, бар из даљине, видјети своју кућу. - Глупости! - љутио се капетан. - Кад ти партизани заузму село, горе заиста имаш да се смрзнеш, то ти је једина перспектива. - Ћопић 1966: 536.

a) У потоњем наведеном примеру - а поћи ћемо у анализи од њега, - дијалошке секвенце започињу плуралним облицима, одакле је јасно да се ради о мноштву (војске). Затим долази збирна именица 'братија', у којој је садржана мало пејоративна квалификација 'четника' од стране њиховог заповедника. Са тога гледишта старешина затим у жижу ставља појединца, апострофира га заменицом 'он', и жали се да овај највише са фронта воли 'видјети своју кућу'. Иако је из контекста јасно да се ради мноштву, оним 'он' унеколико пејоризираним изразима то мноштво је сажето у једнинске облике. 
б) Први пример је прозирнији, и разумљив је кад се сетимо случајева са властитим именима (т. 3.4). У питању је само пејорацијски поступак замене регуларног назива одговарајућом заменицом у средњем роду. Из овако узетог дела текста није ни јасно да је реч о мноштву, али надамо се да ће читалац бити у ситуацији да на основу сопственог говорног искуства препозна тип израза.

5.3. И у следећим примерима аутор заправо описује плуралне ситуације, обичајне поступке и општу сеоску свакодневицу. Он, међутим, своди опште појаве и вишекратне догађаје у јединствене слике и пропраћа их духовитим опаскама о људским наравима.

Зато се на такав пут у ово доба шаљу само старији и јачи, а малишани у то доба остају код кућа, па се џевељају и претурају по ћилимиу у топлој соби, или се са дедом који такођер чува запећак, боду и туцају главама ко овнови и челиче своја темена на тај начин, да с временом постану тврдоглави, и да се не даду свакој шуши пулгерској! - Сремац 1977: 212.

Само ће несташни и безбрижни врапци после Митровдана остати у својим, летошњим, квартирима. Цвркутаће испод стрехе, гложиће се и кавжиће са корисним кокошкама ови незвани гости, кад вредна домаћица баци зрна пред кућу... - Сремац 1977: 213.

Све, све се променило; само домаћи петао посред њих остао још онај лепи, стари, летошғи петао. Покисао, истина, мало и он, и креста му, ко реко би, помодрила, али је ипак поносит; не да познати да му је зима, отима се. Што ти је, боже, левента и старо господство! Тако мора сваки помислити кад га види и покисла и ипак поносита. - Сремац 1977: 213-214.

а) Почетак првог примера описан је множинским формама: да се „у ово доба шаљу само старији и јачи, а малишани у то доба остају код кућа”. Дакле, јасно је да је реч о више истоврсних догађаја у више „кућа” (Интересантно је да се овде потенцира плуралност и уместо обичнијег идиоматизованог 'код куће' стоји 'код кућа'). Но затим се врло суптилним обртом прелази на сингулар, и отвара јединствена упечатљива слика кућног живота са децом која „се џевељају и претурају по ћилимиу у топлој соби, или се са дедом који такођер чува запећак, боду и туцају главама”. У свакој кући је сопствени 'ћилимац', и деда који се са децом на њему игра. Али плуралност догађаја остаје у позадини, а у првом плану је, рекосмо, јединствена слика (Као нека врста контраста према претходној тежњи ка плуралу).

б) Исти поступак примењен је и у другом примеру, где се најпре јављају „безбрижни врапци [...] у својим квартирима”, а онда се њихов цвркут оживљава у слику „испод (једне) стрехе”, а долази и „вредна домаћица”, која баца „зрна пред кућу”.

в) У трећем и не видимо никакав претходни текст, већ непосредно бивамо уведени у слику са поноситим петлом итд.

\section{3. Закључне напомене}

Сажимајући расправу, у прилици смо само да поновимо што је горе речено, а то је да се каткада принудном метонимијом мноштво приказује једнинским облицима општих или заједничких именица. Тај поступак по правилу има улогу стилског активирања и потенцирања израза. 


\section{Лuтература}

Белић А. „О језичкој природи и језичком развитку II.” Изабрана дела. Књ. 1. Београд: Завод за уџбенике, 1998.

Стевановић М. Савремени српскохрватски језик I. - Шесто изд. Београд: Научна књига, 1991.

\section{Извори}

Нушић Б. Хајдуйи. Ваљево: Berlin Company, 2003. - Нушић 2003.

Сремац Ст. Поп Ћира и поп Спира, и Лимунащија на селу. Београд: Просвета, 1977. - Сремац 1977.

Станковић Б. Изабране приповетке. Београд: Просвета, 1957. - Станковић 1957.

Ћопић Б. „Пролом.” Сабрана дјела. Књ. 3. Београд: Београдски издавачки завод, 1966. - Ћопић 1966.

Ћосић Д. „Време отпора.” Лична историја једног доба. Београд: Службени гласник, 2009. - Ћосић 2009.

Ускоковић У. Чедомир Илић. Београд: Политика и Народна књига, 2004. - Ускоковић 2004.

Andrić I. „Mara milosnica.” Sabrana djela. Knj. 7. Zagreb: Mladost, 1963. - Андрић 1963a.

Andrić I. Na Drini ćuprija. Zagreb: Mladost, 1963. - Андрић $1963 б$.

Andrić I. Travnička hronika. Zagreb: Mladost, 1963. - Андрић 1963в.

Domanović R. Satire. Beograd: Nolit, 1967. - Домановић 1967.

Radoje Simić

SINGULAR OF GENERAL (COMMON) NOMINALS WITH A MEANING OF PLURAL IN SERBIAN LANGUAGE

Summary

The author is considering cases of type: „Dear travelers, please cancel your ticket”, and find that the singular 'ticket' does not stand for the individual item of the designated type, but for the plural that is here denoted as the 'distribution' route. We think that this is a 'general' meaning in the real sense of the word. Such and similar examples will be analyzed in this annex.

Key words: noun, singular, plural, meaning, own names. 